\title{
EKSPEDYCJA DRAGONÓW KAPITANA MICHAŁA FLOKA DO PODLASKICH DÓBR BOGUSŁAWA RADZIWIŁŁA - ZABŁUDOWA I ORLI (1660 R.)
}

\section{Michał Sierba}

Centralne Muzeum Włókiennictwa w Łodzi

\author{
ABSTRACT \\ THE EXPEDITION OF CAPTAIN MICHAŁ FLOK'S DRAGOONS INTO \\ BOGUSŁAW RADZIWIŁŁ'S POSSESSIONS IN PODLASIE: ZABŁUDÓW \\ AND ORLA (1660)
}

The presented historical source edition consists of instructions and a passport given to Captain Michał Flok by Prince Bogusław Radziwiłł in 1660, together with a supplement most probably created by Jan Mierzeński. The unit of dragoons led by Michał Flok was meant to overrun Zabłudów and Orla, which belonged to the Radziwiłł family, and retake them from the Lithuanian army. The instructions detail the road which Flok's dragoon unit was supposed to take in order to get to Zabłudów and Orla. Moreover, they explain how to behave towards the people living in the territories along the way and towards the Lithuanian soldiers, their families as well as the inhabitants of the Zabłudów and Orla lands. The supplement contains, among other things, information on what to tell representatives of the army while retaking the lands, how to deal with the soldiers and local inhabitants, how to allocate the dragoons in Zabłudów and Orla, and how to communicate with the Prince and his administration. At the very end of the supplement, the monthly soldier's pay for Captain Flok's unit is indicated. The source edition also includes the passport which was given to Michał Flok and his troops so that they could advance freely towards Podlachia.

Key words: Orla, Zabłudów, Bogusław Radziwiłł, Michał Flok.

Słowa kluczowe: Orla, Zabłudów, Bogusław Radziwiłł, Michał Flok. 


\section{WSTĘP}

Prezentowana edycja źródłowa porusza kwestię odzyskania w 1660 roku dóbr zabłudowskich i orlańskich po zmarłym wojewodzie wileńskim i hetmanie wielkim litewskim Januszu Radziwille przez jego brata stryjecznego Bogusława, koniuszego wielkiego litewskiego, z rąk okupujących je wojsk litewskich. Edytowany dokument został wpisany do księgi zawierającej kopie listów i dokumentów pod tytułem Kopiariusz korespondencji Bogusława Radziwiłła oraz innych materiałów historycznych i publicystyczno-literackich $z$ lat 1657-16721. Księga zawiera 147 kart o rozmiarach $33,5 \times 21,5 \mathrm{~cm}$, zapisanych odręcznie. Kopiariusz przechowywany jest w Bibliotece Narodowej w Warszawie pod sygnaturą Rps III 3092. Omawiany dokument Druga ekspedycja na Podlasie - kopia informacyjej Panu Kapitanowi Flokowi na Podlasie $z$ dragonia idacemu danej wraz z suplementem i paszportem dla kapitana Floka znajdują się na kartach 17-19v. Źródła te zachowały się do naszych czasów tylko jako kopie. Nie udało się dotychczas odnaleźć oryginałów ani innych ich egzemplarzy. Oryginał instrukcji i paszport zostały spisane w Berlinie 20 sierpnia 1660 roku przez Bogusława Radziwiłła. Suplement zaś został sporządzony najprawdopodobniej przez Jana Mierzeńskiego, marszałka wiłkomirskiego, najbardziej zaufanego sługę księcia koniuszego. Wydaje się, że tę wersję spisał w drugiej połowie sierpnia $1660 \mathrm{roku}^{2}$. To on także przekazał instrukcję, wraz z suplementem i paszportem, kapitanowi Flokowi najpóźniej 31 sierpnia $^{3}$. Nie znamy daty spisania edytowanych kopii. Autorzy Katalogu rękopisów Biblioteki Narodowej twierdzą, że Kopiariusz został sporządzony w drugiej połowie XVII wieku w środowisku bliskim Radziwiłłom ${ }^{4}$.

Celem spisania dokumentu było poinstruowanie kapitana Michała Floka, w jaki sposób zajechać i zająć w imieniu Bogusława Radziwiłła dobra zabłudowskie i orlańskie. Dobra zabłudowskie położone były na granicy województwa podlaskiego i powiatu grodzieńskiego, niedaleko dzisiejszego Białegostoku. Majętność orlańska

1 Karty 2-40v zawierają: Kopiariusz listów Bogusława Radziwiłta koniuszego wielkiego litewskiego z lat 1659-1664. Obydwa tytuły zostały nadane nie przez sporządzających te źródła, tylko przez bibliotekarzy. Zob. Katalog rękopisów Biblioteki Narodowej, seria II, t. II: Rękopisy z Biblioteki Załuskich i innych zbiorów polskich zwrócone z Leningradu w latach 1923-1934: sygnatury 3006-3300, oprac. B.S. Kupść, K. Muszyńska, Warszawa 1980, s. 162-171.

2 Wskazuje na to list Mierzeńskiego do swojego pryncypała z Królewca z 6 VIII 1660 r., w którym wysłał m.in. miesięczny wykaz żołdu sugerowany przez kapitana Floka dla jego oddziału. J. Mierzeński do B. Radziwiłła, Królewiec 6 VIII 1660, Archiwum Główne Akt Dawnych [dalej: AGAD], Archiwum Warszawskie Radziwiłłów [dalej: AR], dz. V, sygn. 9646/II, s. 81-86. Różni się on w niektórych kwestiach od wersji ostatecznej, w związku z tym edytowana wersja musiała zostać spisana później po liście od księcia z 9 VIII. B. Radziwiłł do J. Mierzeńskiego, Berlin 9 VIII 1660, AGAD, AR, dz. IV, teka 4, koperta 51, list 161. List ten dotarł zapewne do marszałka wiłkomirskiego 17 VIII, kiedy też na niego odpowiedział w dwóch listach. W jednym z nich zawarł swoje wątpliwości względem wyprawy, gdyż uważał, że siły wysyłane na Podlasie mogą być zbyt szczupłe do zajęcia Orli i Zabłudowa. Obawiał się również reakcji wojskowych litewskich. Wstrzymano wtedy wyjazd Floka wraz z dragonami. J. Mierzeński do B. Radziwiłła, Królewiec 17 VIII 1660, AGAD, AR, dz. V, sygn. 9646/II, s. 87-89, 91.

3 J. Mierzeński do B. Radziwiłła, Królewiec 31 VIII 1660, AGAD, AR, dz. V, sygn. 9646/II, s. 97.

4 Katalog rękopisów Biblioteki Narodowej..., s. 171. 
znajdowała się na Podlasiu w ziemi bielskiej, paręnaście kilometrów na południe od Bielska. W instrukcji dla kapitana Floka zostały omówione sugerowana trasa przejazdu oraz sposób zachowania się względem ludności zamieszkałej w miejscowościach leżących na trasie do podlaskich dóbr księcia koniuszego. Opisano tam także, jakie kroki miał podjąć kapitan Flok wraz z nowymi starostami - Krzysztofem Łopatą i Mikołajem Porębskim - już po dotarciu do majętności zabłudowskiej i orlańskiej. W suplemencie do instrukcji zapisano dodatkowe polecenia, jak również miesięczny przydział żołdu dla poszczególnych dragonów. Niniejsza edycja źródłowa zawiera także paszport dla oddziału Michała Floka, który miał gwarantować mu swobodny przejazd do Radziwiłłowskich dóbr podlaskich.

Kapitan Michał Flok ${ }^{5}$ herbu własnego był najprawdopodobniej Inflantczykiem. Andrzej Rachuba wymienia go w 1655 roku jako kapitana regimentu dragonii Bogusława Radziwiłła pod dowództwem oberszter-lejtnanta Eberharda von Puttkamera, który przebywał wtedy na Podlasiu' 6 . W marcu 1658 roku został odnotowany jako dowódca kompanii dragonii księcia Bogusława, wchodzącej w skład regimentu dragonii pod dowództwem podpułkownika Wilhelma von Blocka ${ }^{7}$. W drugiej połowie 1659 roku wraz z całym regimentem znajdował się w zajętych przez Bogusława Radziwiłła Birżach ${ }^{8}$. Pod koniec sierpnia 1660 roku wyruszył na czele 150 dragonów na Podlasie w celu zajęcia dóbr zabłudowskich i orlańskich ${ }^{9}$. Powrócił do księcia Bogusława najprawdopodobniej pod koniec października lub w listopadzie 1661 roku $^{10}$. Brał udział w kampanii przeciw Moskwie (XI 1661-II 1662) i w zdobyciu Wilna $^{11}$. Pod komendą radziwiłłowską służył do 10 grudnia 1661 roku, gdy książę przekazał chorągwie Michała i Fromholdta Floków królowi Janowi Kazimierzowi. Weszły one wtedy w skład wojska litewskiego ${ }^{12}$. Jan Władysław Poczobut Odlanicki w 1665 roku odnotował Floka w swym pamiętniku jako oberszter-lejtnanta

5 Znane są także inne pisownie jego nazwiska: Flock, Flek, Pflock. A. Boniecki, Herbarz Polski, t. V, Warszawa 1902, s. 299; S. Konarski, Platerowie [w:] Materiaty do biografii, genealogii i heraldyki polskiej. Źródta i opracowania, t. IV, Buenos Aires-Paryż 1967, s. 44; J. Ostrow ski, Księga herbowa rodów polskich, Warszawa 1898; Polska encyklopedia szlachecka, t. V, oprac. M. Dmowski, S.J. Strykoń-Kasprzycki, Warszawa 1936, s. 228.

6 A. Rachuba, Oficerowie armii litewskiej z armii szwedzkiej i oficerowie armii szwedzkiej $w$ armii litewskiej w latach 1655-1660 [w:] Wojny pótnocne w XVI-XVIII w. W czterechsetlecie bitwy pod Kircholmem, red. B. Dybaś, Torun 2007, s. 158.

7 S. Augusiewicz, Przebudowa wojska pruskiego w latach 1655-1660. Uźródel wczesnonowożytnej armii, Oświęcim 2014, s. 298-299.

8 Idem, Garnizon Birż w latach 1659-1687 i jego komendant Karol Karlick von Nezetitz [w:] Ustrój - polityka - kultura. Studia ofiarowane Profesor Stefanii Ochmann-Staniszewskiej, red. R. Kołodziej, J. Maroń, Wrocław 2011, s. 282.

9 J. Mierzeński do B. Radziwiłła, Królewiec 31 VIII 1660, AGAD, AR, dz. V, sygn. 9646/II, s. 97.

10 Dnia 23 X 1661 r. Bogusław Radziwiłł wystawił mu paszport na przemarsz. AGAD, AR, dz. IVa kopie, sygn. 746, s. 67.

11 Za zwrócenie na to uwagi dziękuję prof. Stanisławowi Augusiewiczowi.

12 B. Radziwiłł, Autobiografia, wyd. T. Wasilewski, Warszawa 1979, s. 148; S. Uruski, Rodzina. Herbarz szlachty polskiej, t. IV, Warszawa 1907, s. 48. 
dragońskiego dowodzącego całym pułkiem hetmana polnego litewskiego Michała Kazimierza Paca ${ }^{13}$. Za zasługi na polach bitew został awansowany na pułkownika, zaś w 1673 roku nadano mu indygenat ${ }^{14}$. W 1676 roku udowodnił swoje szlachectwo, złożył przysięgę, po czym jego indygenat został zatwierdzony ${ }^{15}$. Możliwe, że wziął ślub z Małgorzatą z Platerów, córką Gotarda Platera i Jadwigi Elżbiety von Tiesenhausen. Po 1676 roku Michał Flok kupił za 30000 złotych dobra od Fabiana Platera - brata Małgorzaty ${ }^{16}$. Przy dzisiejszym stanie badań nie wiemy nic więcej o życiu Michała Floka.

Sama kwestia pretensji wojska litewskiego tak zwanego starego zaciągu do dóbr po księciu Januszu jest dość skomplikowana. Bez wchodzenia w zbędne szczegóły należy opisać główne etapy konfliktu przed ekspediowaniem regimentu kapitana Michała Floka do dóbr podlaskich Radziwiłłów ${ }^{17}$.

W 1654 roku rozpoczęła się wojna Rzeczypospolitej z Moskwą. Nieopłacone wojsko litewskie chciało porzucić służbę. By je zatrzymać, komisarze króla Jana Kazimierza złożyli 3 grudnia 1654 roku pisemną deklarację wypłacenia żołdu do 9 sierpnia 1655 roku. Dziesięć dni później to samo uczynił hetman wielki litewski Janusz Radziwiłł, asekurując wypłatę pieniędzy na swoich dobrach. W lipcu 1655 roku Szwecja zaatakowała Rzeczpospolitą. Termin wypłaty żołdu nie został dotrzymany. Janusz Radziwiłł 17 sierpnia 1655 roku podpisał umowę jaswojnieńską ze Szwedami, a w październiku - w Kiejdanach. Część wojska litewskiego natomiast zawiązała antyradziwiłłowską i antyszwedzką konfederację w Wierzbołowie. Król, by przeciągnąć konfederatów na swoją stronę, wydał 8 września 1655 roku w Wolborzu akt, którym przekazywał litewskie majętności stronników Szwedów - Janusza i Bogusława Radziwiłłów - na rzecz konfederatów. Dwa dni później w Sulejowie nadał konfederatom wszystkie dobra w Rzeczypospolitej należące do Janusza Radziwiłła. Wojska obdarowane w Sulejowie określano później jako stary zaciąg ${ }^{18}$.

Postęp wojsk szwedzkich doprowadził do ucieczki Jana Kazimierza na Śląsk, gdzie przebywał on do początku 1656 roku. Powracający do kraju król potwierdził 8 lutego 1656 roku w Samborze wojsku litewskiemu przekazanie dóbr po nieżyjącym już Januszu Radziwille (zm. w nocy z 30 na 31 XII 1655 r.). Dokument ten wyłączał jednak z donacji majątki przynależne wdowie po Januszu - Marii „Wołoszce”" ${ }^{\text {. Nie- }}$ zadowolone wojsko 8 kwietnia 1656 roku we Lwowie wymusiło na Janie Kazimie-

13 J.W. Poczobut Odlanicki, Pamiętnik (1640-1684), wyd. I.J. Kraszewski, L. Potocki, Warszawa 1877, s. 91; idem, Pamiętnik (1640-1684), wyd. A. Rachuba, Warszawa 1987, s. 214-215.

14 Volumina Legum, t. V, oprac. J. Ohryzko, Petersburg 1860, s. 88.

15 Ibidem, s. 219.

16 S. Konarski, op. cit., s. 42, 44.

17 Radziwiłłowie do swoich dóbr podlaskich zaliczali także majętność zabłudowską, mimo że administracyjnie leżała ona w granicach powiatu grodzieńskiego w województwie trockim.

18 AGAD, AR, dz. II, sygn. 1302; A. Rachuba, Sprawa dóbr Radziwitlów birżańskich w latach 1655-1662, „Miscellanea Historico-Archivistica” 1997, t. VII, s. 51-52. Na ten temat również: idem, Konfederacja Kmicicowska i Zwiazek Braterski wojska litewskiego w latach 1660-1663, Warszawa 1989; idem, Konfederacje wojska litewskiego w latach 1655-1663, Zabrze 2010; K. Żojdź, Jan Mierzeński. Klient i rezydent Bogustawa Radziwilta w latach 1656-1665, Oświęcim 2012.

19 AGAD, AR, dz. II, sygn. 1309. 
rzu powrót do ustaleń z Sulejowa ${ }^{20}$. Między 2 maja a 30 lipca król jeszcze dwukrotnie potwierdził staremu zaciągowi prawa do dóbr po Januszu Radziwille. Prawa wojska litewskiego do tych majętności zostały jednak podważone przez ustalenia polsko-brandenburskie z Welawy i Bydgoszczy (9 IX i 6 XI 1657 r.). W ramach traktatów i osobnego dyplomu Bogusław Radziwiłł doczekał się amnestii, zapewnienia zwrotu dóbr własnych i uznania przez Jana Kazimierza praw koniuszego litewskiego do dóbr po Januszu Radziwille ${ }^{21}$. Książę zyskał więc mocny argument w walce o dobra brata stryjecznego. Koniuszy litewski pisał listy do króla, swoich krewnych i przyjaciół w celu uzyskania pomocy w odzyskaniu majętności. Zaczął też zabiegać o to u wojska ${ }^{22}$.

O realizację planów restytucyjnych księcia Bogusława zabiegała także para królewska, która chciała pozyskać koniuszego litewskiego do swych planów politycznych. Wojsko litewskie było jednak przeciwne wszelkim nakazom króla i Radziwiłła w sprawie oddania omawianych majętności bez odpowiedniej rekompensaty. Armia zawiązała konfederację i groziła porzuceniem służby, a w ówczesnej sytuacji militarno-politycznej miałoby to katastrofalne skutki dla Rzeczypospolitej. Taka postawa wojska zmusiła Jana Kazimierza do chwilowej rezygnacji z odebrania mu dóbr Radziwiłłowskich. Król zasugerował koniuszemu litewskiemu cierpliwość, kaptowanie zwolenników i wyczekiwanie na bardziej sprzyjające okoliczności ${ }^{23}$.

Takie pojawiły się w marcu 1660 roku, gdy doszło do najazdu wojsk moskiewskich Iwana Chowańskiego na Podlasie. Kniaź chciał niespodziewanym atakiem zniszczyć siły pisarza polnego litewskiego Aleksandra Hilarego Połubińskiego, znajdujące się na tych terenach - jednak bez powodzenia. Armia Chowańskiego opuściła Podlasie około 10 marca $^{24}$. Po odejściu nieprzyjaciela żołnierze litewscy powrócili do Orli i Zabłudowa.

Zaistniałą sytuację postanowił wykorzystać Bogusław Radziwiłł. 6 marca 1660 roku napisał instrukcję dla swoich klientów Krzysztofa Łopaty i Mikołaja Porębskiego w sprawie odzyskania Zabłudowa i Orli. Nakazał im udać się do tych miejscowości, a po drodze informować, że ciągnie za nimi oddział wojskowy. Wysłannicy Bogusława mieli na miejscu wybadać atmosferę w stacjonującym tam wojsku

20 Ibidem, sygn. 1311.

21 Punkt 20 traktatu welawskiego restytuował dobra Bogusława Radziwiłła. Die Staatsverträge des Herzogtums Preussen, wyd. S.H. Doleze1, Köln 1971, s. 191. Nie było tam mowy o dobrach Janusza Radziwiłła. 6 XI 1657 r. w Bydgoszczy król Jan Kazimierz osobnym dyplomem kasował wszystkie donacje dóbr zmarłego Janusza Radziwiłła na rzecz wojska litewskiego i przyznawał prawa do sukcesji po nim księciu Bogusławowi. AGAD, AR, dz. II, sygn. 1337. Było to tylko osobiste zobowiązanie monarchy względem Bogusława Radziwiłła. Prawnymi sukcesorkami nadal jednak były Anna Maria Radziwiłłówna - córka Janusza Radziwiłła - i wdowa po nim - Maria z Lupulów, zwana Wołoszką. Zob. T. Wasilewski, Walka o spadek po księżnej Marii Wołoszce, wdowie po Januszu Radziwille w latach 1660-1690, „Miscellanea Historico-Archivistica” 1989, t. III, s. 292-308.

22 A. Rachuba, Sprawa dóbr..., s. 57.

23 Ibidem, s. 57-60, 63-65.

24 J. Hlebowicz do B. Radziwiłła, Słonim 11 III 1660, AGAD, AR, dz. V, sygn. 5226, s. 141; F. Ror do B. Radziwiłła, Zernin 3 III 1660, AGAD, AR, dz. V, sygn. 13276, s. 5; K. Kossarzecki, Kampania roku 1660 na Litwie, Zabrze 2005, s. 144. 
litewskim. W miarę swoich możliwości mieli zająć te dobra w imieniu Radziwiłła, a w przypadku niepowodzenia misji ostentacyjnie protestować przeciw bezprawiu i odjechać25. Planu tego nie udało się zrealizować.

W kwietniu 1660 roku w Drohiczynie odbywała się sesja wojskowa, podczas której Krzysztof Łopata i Mikołaj Porębski kontaktowali się z pisarzem polnym litewskim. Ten stwierdził, że na tamtą chwilę nie było możliwe oddanie dóbr Radziwiłłowskich ze względu na nastroje i konflikty w wojsku litewskim. Połubiński zapytany o to, czy Bogusław mógłby zajechać sporne dobra, odpowiedział, ,że nie życzy tego, gdyż wojsko nie tylko temu jest sprzeczne, ale i od Króla JMści nie ujęte”. Obaj wysłannicy Radziwiłła sugerowali, by z zajazdem dóbr poczekać, aż wojsko wyruszy na Litwę, by walczyć z armią moskiewską, i pozostawi dobra bez większej ochrony ${ }^{26}$. Należy również pamiętać, że 3 maja 1660 roku w Oliwie podpisano pokój kończący wojnę Rzeczypospolitej ze Szwecją. Jednym z punktów porozumienia był zwrot spadkobiercom majątków po Januszu Radziwille. Książę Bogusław wykorzystywał to do podkreślenia swych aspiracji względem dóbr po hetmanie wielkim litewskim, mimo że w traktacie za dziedziczkę tych dóbr uznano Annę Marię Radziwiłłównę.

Bogusław Radziwiłł posłuchał uwag swych sług i czekał, aż wojsko uda się na Litwę. W czerwcu 1660 roku Rzeczpospolita podjęła ofensywę przeciwko armii moskiewskiej. W Orli pozostali nieliczni żołnierze, kobiety, dzieci i ich dobytek. Gdy Litwini odeszli daleko na wschód, książę koniuszy postanowił odzyskać Zabłudów i Orlę ${ }^{27}$. W tym celu pod koniec sierpnia wysłał z Prus Książęcych oddział 150 dragonów dowodzonych przez kapitana Michała Floka ${ }^{28}$. Oddział ten wraz z Krzysztofem Łopatą i Mikołajem Porębskim 11 września zajechał i zajął Zabłudów ${ }^{29}$. Dwa dni później część dragonów z Mikołajem Porębskim zajęła Orlę, gdzie zastał ,jeno żony żołnierskie, a kilkunastu towarzystwa" ${ }^{30}$. Większość żołnierzy litewskich wyjechała z Orli, część jednak została, podobnie jak Andrzej Podolec, który pełnił wcześniej funkcję zarządcy dóbr z ramienia Połubińskiego. Żołnierze litewscy oskarżyli dragonów radziwiłłowskich o rabunki i pobicia. Działania księcia Bogusława spotkały się z oburzeniem w wojsku litewskim - nie tylko prostych żołnierzy, ale także kadry dowódczej. Armia stojąca na Białorusi zapowiadała porzucenie służby i odbicie Orli

25 B. Radziwiłł, Ekspedycja podlaska Panu Łopacie i Panu Porembskiemu dana dnia 6 marca w Królewcu 1660, AGAD, AR, dz. IVa kopie, sygn. 745, s. 181-184.

26 K. Łopata i M. Porębski do B. Radziwiłła, Wasilków 25 IV 1660, AGAD, AR, dz. V, sygn. 12196, s. $1-3$.

27 Cała akcja restytucyjna została poprzedzona udanymi zabiegami Jana Mierzeńskiego i posła brandenburskiego Johanna von Hovenbecka na konwokacji warszawskiej, mającymi na celu uzyskanie poparcia dworu dla odzyskania przez Radziwiłła Zabłudowa i Orli. Jan Kazimierz i Mikołaj Prażmowski, kanclerz wielki koronny, zobowiązali się wydać marszałkowi wiłkomirskiemu uniwersały, a także wyznaczyć komisarzy do odebrania tych dóbr. Dnia 19 VII 1660 r. król wydał Mierzeńskiemu uniwersały do Aleksandra Hilarego Połubińskiego i Władysława Jerzego Chaleckiego, strażnika wielkiego litewskiego, w których nakazywał opuszczenie przez podległe im wojska majętności zabłudowskiej i orlańskiej. Narodowe Historyczne Archiwum Białorusi w Mińsku, f. 694, op. 1, sygn. 295, s. 34-40.

28 J. Mierzeński do B. Radziwiłła, Królewiec 31 VIII 1660, AGAD, AR, dz. V, sygn. 9646/II, s. 97.

29 K. Łopata do B. Radziwiłła, Zabłudów 21 IX 1660, AGAD, AR, dz. V, sygn. 8916, s. 5.

30 M. Porębski do B. Radziwiłła, Orla 25 IX 1660, AGAD, AR, dz. V, sygn. 12916, s. 5-6. 
i Zabłudowa ${ }^{31}$. Na wypadek przyszłego odwetu wzniesiono palisadę dookoła dworu orlańskiego i zabłudowskiego. Dla ochrony i bezpieczeństwa w Zabłudowie i Orli pozostawiono dragonów Floka ${ }^{32}$.

Edycja tekstu została przeprowadzona na podstawie instrukcji wydawniczej Kazimierza Lepszego ${ }^{33}$. Pisownia została zmodernizowana, tak by odpowiadała dzisiejszym standardom. W związku z tym, że w tekście XVII-wiecznym nie pojawiała się litera „'”, została ona wstawiona w wyrazach, które dziś pisze się z użyciem tej litery, na przykład okopow zostało zamienione na okopów. Wstawiano także - tam,

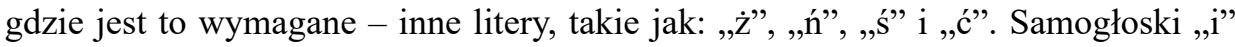
$\mathrm{i}$,y”, a także spółgłoskę ,j” w tekście modernizowano według wskazówek instrukcji wydawniczej, co tyczy się także innych niewymienionych tu liter. Wyeliminowano również podwójne litery w niektórych słowach (np. zamiast affectem zastosowano formę afektem). Do często modernizowanych wyrazów należały słowa dragon i wyjdzie (w mianowniku i przypadkach zależnych), które w dokumencie były pisane: dragan i wyndzie. Zmodernizowano także nazwy miejscowości oraz ich odmianę - zamiast Zabludowiu i Orlu w edycji zastosowano formy Zabludowie i Orli. Ponieważ te ostatnie cztery modernizacje były bardzo częste, nie zamieszczano informacji o nich w przypisach tekstowych. Rozwiązano także skróty słów dziś już niestosowane, między innymi: sta - starosta, pndze - pieniadze, Rpej` i Rzpej` - Rzeczypospolitej itp. Pojawiły się też w tekście końcówki -go zapisane jako: - ${ }^{\circ}$. Miejsca te opatrzono przypisami tekstowymi. Zachowano pisownię skrótów: Ks.J.M. - Księcia Jego Miłości, J.M. - Jego Miłości, P. - Pan, PP. - Panowie, J.M.P. - Jego Miłość Pan, J.K.M. - Jego Królewska Miłość. W związku z brakiem konsekwencji w samym źródle, wszędzie zachowano formę skrótową od słowa Pan, niezależnie czy była pisana skrótowo, czy w pełnej formie.

31 K. Kłokocki do B. Radziwiłła, Nieśwież 26 XI 1660, Słuck 30 XI 1660, AGAD, AR, dz. V, sygn. 6865/II, s. 5-6, 11-14; K. Łopata do B. Radziwiłła, Zabłudów 25 XI 1660, AGAD, AR, dz. V, sygn. 8916, s. 17; B. Olszewski do B. Radziwiłła, Orla 29 X 1660, AGAD, AR, dz. V, sygn. 10816/I, s. 169 171; B. Radziwiłł do K. Łopaty, Królewiec 3 XII 1660, AGAD, AR, dz. IVa kopie, sygn. 748, s. 36; K. Kossarzecki, op. cit., s. 337-338.

32 Biblioteka Narodowa, Rps III 3092, k. 17-19v. Samo zajęcie dóbr orlańskich i zabłudowskich przez Bogusława Radziwiłła nie kończyło konfliktu z wojskiem litewskim, który trwał aż do końca 1662 r. Należy także podkreślić, że odzyskanie Orli i Zabłudowa było jedynie częścią akcji restytucyjnej. Rozpoczęła się ona od odebrania Gosiewskim w 1658 r. Kiejdan i Birż. W 1660 r. książę Bogusław zajął także m.in. Bielicę, Taurogi i Nowe Miasto. Więcej na temat sporu Radziwiłłów birżańskich z armią litewską w dobie potopu szwedzkiego i wojny z Moskwą zob. A. Rachuba, Sprawa dóbr..., s. 51-70; M. Sierba, Radziwiltowskie dobra Orla (1585-1695), Białystok 2017, s. 62-76.

$33 \mathrm{~K}$. Lepszy, Instrukcja wydawnicza dla źródet historycznych od XVI do połowy XIX w., Warszawa 1957. 


\section{Tekst źródłowy \\ Druga ekspedycja na Podlasie ${ }^{1}$}

Kopia informacyjej P. Kapitanowi Flokowi ${ }^{2}$ na Podlasie z dragonią idącemu danej

Org.: Kopiariusz korespondencji Bogusława Radziwiłła oraz innych materiałów historycznych i publicystyczno-literackich z lat 1657-1672, Biblioteka Narodowa, Rps III 3092, k. 17-19v.

[k. 17] Wyni[e]ść z[e] stanowiska zarazem ${ }^{3}$ nie czyniąc i rachunku w powiecie insterburski ${ }^{4}$, jeśliby go zwłaczano ${ }^{5}$ i odkładano i iść Prusami do Ełku ${ }^{6}$. Z Ełku jako na[j]prostszą drogą iść do Zabłudowa, powiadając, że idzie do obozu koronnego, a w ciągnieniu na[j]mniejszej krzywdy i uciążenia tak w dobrach królewskich i duchownych, jako i szlacheckich nie czyniąc - okupów i ugód żadnych nie brać pieniężnych.

[k. 17v] Przeprawić się na rzece Biebrzy ${ }^{7}$ pod Osowcem ${ }^{8}$, skąd przez knyszyńskie wsi $^{9}$ iść do Karakul ${ }^{10}$, ale tam na pokarm tylko zmierzać. A i tam nie powiadać, że idzie do Zabłudowa, żeby się żołnierze albo ich czeladź, co są na reklinatoriach ${ }^{11}$, nie ostrzegli.

${ }^{1}$ W sumie $w 1660$ r. byly trzy plany odzyskania podlaskich dóbr Radziwitlowskich. Pierwsza ekspedycja nie doszła do skutku. Nie miat być to zajazd wojskowy, tylko próba wystania z misja na Podlasie Mikołaja Porębskiego i Krzysztofa Łopaty. Mieli oni pokojowo przejać Zabłudów i Orlę, grożąc jednak, że ciagnie za nimi wojsko radziwiłlowskie. B. Radziwitł do K. Łopaty i M. Porębskiego, Królewiec 6 III 1660, AGAD, AR, dz. IVa kopie, sygn. 745, s. 183-184. O drugim planie wspomina Jan Mierzeński w liście z 6 VIII 1660 r. Pisat on o instrukcji dla kapitana Floka, która miata zostać przettumaczona na język niemiecki, gdyż kapitan nie znat języka polskiego lub znat go słabo. J. Mierzeński do B. Radziwilła, Królewiec 6 VIII 1660, AGAD, AR, dz. V, sygn. 9646/II, s. 81. Wtedy wyprawa nie doszła do skutku. Ten plan ekspedycji należy traktować, w kontekście tytulu wspomnianego powyżej dokumentu, jako pierwszy.

2 Michat Flok (Flock) - kapitan dragoński w stużbie Bogustawa Radziwiłta.

3 W znaczeniu: szybko, natychmiast.

${ }_{4}$ Insterburg-dzisiejszy Czerniachowsk w obwodzie kaliningradzkim należacym do Rosji. Wcześniej miasto w granicach Prus Ksiązęcych.

5 W znaczeniu: opóźniano.

6 Ełk-miasto w dzisiejszym województwie warmińsko-mazurskim, w powiecie ełckim, nad Jeziorem Ełckim. W XVII w. Ełk leżat w granicach Prus Ksiązęcych.

7 Biebrza-prawy doplyw Narwi.

8 Osowiec - obecnie Osowiec-Twierdza, osada polożona $w$ dzisiejszym województwie podlaskim, w powiecie monieckim, nad rzeka Biebrza. W czasach I Rzeczypospolitej Osowiec należat do województwa mazowieckiego.

9 Chodzi o wsie wchodzace $w$ sktad starostwa knyszyńskiego, które często byto $w$ dokumentach taczone ze starostwem goniądzkim. Starostwa te leżaty w ziemi bielskiej województwa podlaskiego.

${ }^{10}$ Karakule - wieś położona dziś w województwie podlaskim w powiecie biatostockim. W XVII w. wchodziła w skład Radziwiłłowskich dóbr zabłudowskich położonych $w$ powiecie grodzieńskim, $w$ województwie trockim, niedaleko granicy z województwem podlaskim.

11 Wnaczeniu: na leżach, na kwaterach. 
Przyszedszy do Zabłudowa stanąć we dworze w domu nowym wielkim ze stem ${ }^{12}$ dragonii i w nim się oparkanić ${ }^{13}$ i przywałek ${ }^{14}$ dać, a P. Łopata ${ }^{15}$ starosta $^{\text {a }}$ zabłudowski drzewo na palisadę wozić i poddanym robić koło niej i koło przywałku każe. A do Orli wyprawić pię[ć]dziesiąt dragonów z porucznikiem, który niech z dragonami w kamienicy albo w domu wielkim drewnianym stoi, dawszy koło niego parkan albo palisadę, koło czego P. Porębski ${ }^{16}$ dozorca majętności orlańskiej robić poddanym rozkaże.

Tak do Zabłudowa idąc, jako i tam stanąwszy, głosić, że sam Ks.J.M. idzie z wojskiem Kurfista J.M. ${ }^{17}$ i swym własnym na usługę Rzeczypospolitej ${ }^{\text {b }}$.

Żołnierzom, żonom i czeladzi żołnierskiej, którą zastaną w mieście zabłudowskim i orlańskim, także na wsiach do Zabłudowa, Orli i do folwarków zabłudowskich i orlańskich należących, żadnego ${ }^{c}$ bezprawia i gwałtu nie czynić, tylko powiedzieć im żeby zarazem ustępowali i więcej w majętnościach, dworach i wsiach Ks.J.M. nie gospodarowali, ponieważ nie tylko dawniejsze pakta z Kurfistem J.M. ${ }^{18}$ i konstytucje $^{19}$, ale i świeże z[e] Szwedami zawarte ${ }^{20}$ przywrócenie tych dóbr warowały i rozkazały, i wola na to J.K.M., i Rzeczypospolitej ${ }^{\mathrm{d}}$ zaszła, której jeśliby się sprzeciwiać chcieli, daliby do naruszenia pokoju zawartego przyczynę i do tego żeby ich gwałtem z tych dóbr rugowano i wyrzucano. A w tenże czas P. Pisarz G[rodzki] Brański ${ }^{21}$ z P. Łopatą i P. Porębskim mieszczanom i poddanym wszytkim majętności zabłudowskiej, orlańskiej, także niewodnickiej, doylidzkiej, karakulskiej, sobolewskiej i białostockiej ${ }^{22}$ przykażą, aby się żołnierzom, ani ich czeladzi nie wysługowali,

a Stowo zapisane skrótem: sta'.

b Stowo zapisane skrótem: Rpey'.

'Stowo zapisane skrótem: żadne ${ }^{\circ}$.

d Stowo zapisane skrótem: Rpey`.

12 W znaczeniu: $z$ setka.

13 W znaczeniu: postawić ptot, parkan, palisadę.

14 W znaczeniu: usypać wat.

15 Krzysztof Łopata - zaufany stuga Bogustawa Radziwitta, starosta zabludowski w latach 1660 1662, komisarz stucki od 1664 r. M. Mituński, Zarzad dóbr Bogusława Radziwilta w latach 1636-1669 [w:] Administracja i życie codzienne w dobrach Radziwiltów XVI-XVIII w., red. U. Augustyniak, Fasciculi Historici. Seria Nowa, t. IX, Warszawa 2009, s. 274.

16 Mikołaj Porębski - stuga Bogustawa Radziwilta, starosta orlański w latach 1660-1665. M. Mituński, op. cit., s. 276.

17 Elektora brandenburskiego Fryderyka Wilhelma.

18 Traktaty zawarte w Welawie (9 IX 1657) i Bydgoszczy (6 XI 1657).

19 Chodzi o konstytucje: „Approbacya pactorum z Kurfistem IMcia Brandenburskim” przyjęta na sejmie warszawskim $1658 \mathrm{r}$.; , Exempty żolnierskie”, „Executio pactorum z Kurfirsztem Iego Mcia zawartych" przyjęte na sejmie warszawskim 1659 r. Zob. Volumina constitutionum, $t$. IV, vol. 1, oprac. K. Fokt, S. Grodziski, M. Kwiecień, Warszawa 2015, s. 378-379; Volumina legum, t. IV, wyd. J. Ohryzko, Petersburg 1860, s. 239, 283-284.

20 Traktat pokojowy w Oliwie z 3 V 1660 r. kończacy wojnę między Szwecją a Rzeczpospolita.

${ }_{21}$ Benedykt Olszewski (zm. ok. 1691) - zaufany stuga Bogusława Radziwilta, pisarz grodzki brański w latach 1658-1680, podczaszy bielski od 1681 r. B. Radziwitt, Autobiografia, wyd. T. Wasilewski, Warszawa 1979, s. 341; M. Mituński, op. cit., s. 275.

${ }^{22}$ W sktad klucza zabludowskiego wchodziło pięć wyżej wspomnianych wtości. Majętności bialostockiej nie należy mylić z dobrami białostockimi leżącymi na terenie ówczesnego województwa podlaskiego. W tym wypadku chodzi o folwark Białostoczek, zwany takie Koroszowo. 
żadnego posłuszeństwa nie czynili, żadnych czynszów, podwód, stacji i na[j]mniejszej rzeczy nie dawali, owszem, aby gotowi byli przy dragonach bronić się, jeśliby na nich następowali i gwałtem im brać co chcieli.

Tego mianowicie przestrzegać, żeby przy ustępowaniu bydeł i koni nie zabierali poddanym, także zbóż i rzeczy jakich, i doglądać aby wracali - jeśli co wzięli.

Jeśliby podczas zajazdu albo przed nim krótko wzięli co bydeł, koni i zboża żołnierze albo ich czeladź poddanym i przechowywali u PP. Sąsiadów, tedy P. Łopata z P. Porębskim po przyjacielsku upomną się u nich, aby to oddali poddanym. A jeśliby nie chcieli - wziąc swoje, sąsiedzkiego nic nie biorąc jednak, ani gwałtu nie czyniąc w domach sąsiedzkich.

Iż majętności niewodnickiej i doylidzkiej wieczność Ks.J.M. należy lubo są w zastawie, tedy do [k. 18] oswobodzenia aich $\mathrm{z}$ rą ${ }^{\mathrm{a}}$ żołnierskich jako mych własnych dopomóc J.P. Marszałkowi Wiłkomirskiemu ${ }^{23}$ i innym dzieci nieboszczyka ${ }^{b}$ P. Otten$[\mathrm{h}] \mathrm{auza}^{24}$ opiekunom.

Dragoni[e] mieć zawsze w kupie, a być ostrożnym P. Kapitan ${ }^{25}$ powinien będzie. A jeśliby do dworu albo wsi jakiej posłać na ochronę od żołnierza trzeba było, tedy nie posyłać po jednemu albo po dwóch dragonów, ale tyle, ile potrzeba ukaże. W czym znosić się z [e] starostami i bez ich wiadomości nie wyprawować.

Dragoni[e] mieć w dobrym porząaku i dyscyplinie, nie pozwalając im swej woli, a mianowicie zdzierstwa i łupiestwa, i szkodzenia poddanych jawnego i tajemnego, także broniąc im zabiegów ${ }^{26}$ do wsi sąsiednich - tak królewskich, jako i szlachec$\mathrm{kich}^{27}$ - ale je zawsze na miejscu w dobrym rządzie trzymając, a występnych i swawolnych karząc.

Na włościanach żadnych eksa[k]cji ${ }^{28}$ czynić nie będzie, przestawając, na tej którą dla niego, oficerów i dragonów postanowiona i na poddanych włożona będzie

a-a Nad tymi trzema wyrazami sa zapisane cyfry. Najwyraźniej pisarz, przepisując tekst, pomylit kolejność $i$ w ten sposób chcial naprawić pomyłkę. W oryginale: $\mathrm{z}^{2} \mathrm{rą}^{3} \mathrm{ich}^{1}$.

b Stowo zapisane skrótem: Nieb.

${ }^{23}$ Jan Mierzeński (zm. 1665) - najbardziej zaufany sługa Janusza, potem Bogusława Radziwilta, podstoli wolkowyski $w$ latach 1647-1648, marszatek witkomierski w latach 1653-1665. Metryka litewska. Księga wpisów nr 131, wyd. A. Rachuba, Warszawa 2001, s. 460; M. Mituński, op. cit., 274; K. Żojdź, Jan Mierzeński. Klient i rezydent Bogusława Radziwilta w latach 1656-1665, Oświęcim 2012; T. Wasilewski, Mierzeński Jan [w:] Polski Stownik Biograficzny [dalej: PSB], t. XXI, 1976, s. 18-20.

24 Jan von Ottenhauz vel Ottenhausen - stuga Krzysztofa II i Janusza Radziwiltów, oberszter-lejtnanta w piechocie księcia Janusza, któremu towarzyszyt w chwili śmierci w Tykocinie. W $1637 \mathrm{r}$. Janusz Radziwitl chciat ustanowić go zarzadca dóbr orlańskich. J. Radziwilt do K. Radziwilta, Warszawa 23 III 1637, AGAD, AR, dz. IV, teka 16, koperta 183, s. 27; A. Rachuba, Oficerowie armii litewskiej $z$ armii szwedzkiej $i$ oficerowie armii szwedzkiej $w$ armii litewskiej $w$ latach 1655-1660 [w:] Wojny pótnocne w XVI-XVIII w. W czterechsetlecie bitwy pod Kircholmem, red. B. Dybaś, Toruń 2007, s. 157. Zob. AGAD, AR, dz. V, sygn. 11135.

${ }_{25}$ Kapitan Michat Flok (Flock).

26 W znaczeniu: wypraw, zajazdów.

27 Dobra orlańskie graniczyly na wschodzie z Puszcza Białowieska, na poludniu ze starostwem kleszczelowskim, na zachodzie z włościa boćkowska, na pólnocnym zachodzie ze starostwem i leśnictwem bielskim, a na pótnocy z dobrami szczytowskimi.

28 W znaczeniu: wymuszenia, bezprawne wybieranie, rabunek. 
ordynaryjej, która ma być taka jaką w Prusiech brali. Jednak, iż w majętnościach Ks.J.M. łacniej być może o żywność niż o pieniądze, tedy P. Pisarz Grodzki Brański z P. Łopatą tak zordynują, żeby co miesiąc częścią żywnością, częścią pieniędzmia ta ordynaryja wydawana była. A jeśliby wydanie jej poddani zwłaczali, tedy w ten czas dla odebrania jej przy tym kogo starosta ześle, posłać co dragonom.

O zajeździe tych majętności dawać znać Ks.J.M. i po tym oznajmować Ks.J.M. o wszytkim, na co P. Starosta ${ }^{\mathrm{b}}$ ma dawać posłańców do Jansborka ${ }^{29}$, a z Jansborka do Królewca przysłane będą listy.

\author{
${ }^{\mathrm{c}} \mathrm{L}$ [ocus] S[igilli] \\ Wielka pieczęć Ks.J.M.
}

\title{
Suplement informacyjej
}

Według memoriału od Ks.J.M. danego w odebraniu majętności i gospodarowaniu w nich sprawować się. Mianowicie mieć generałów i stronę szlachtę dla prawnego objęcia majętności i oświadczyć się nimi, że Ks.J.M. ex competentia, którą ma z prawa pospolitego, pakt Rzeczypospolitej ${ }^{\mathrm{z}} \mathrm{z}$ Kurfistem J.M. uczynionych ${ }^{30}$, konstytucji o wrócenie dóbr tych napisanych ${ }^{31}$ i świeżych z[e] Szwedami pakt zawartych ${ }^{32}$. Dobra te na się i Księżniczkę J.M.P. Wojewodziankę̧3 odbiera. W czym stosuje się do samego woli K.J.M., którą w uniwersałach do PP. Pułkowników wydanych wyrażać raczy.

Uniwersały te do J.P. Pisarza Polnego [Wielkiego Księstwa Litewskiego] ${ }^{34}$, do J.P. Strażnika ${ }^{\mathrm{e}}$ Wielkiego Księstwa Litewskiego ${ }^{\mathrm{e} 35}$ i do J.P. Chorążego Orszańskiego ${ }^{36}$.

a Stowo zapisane skrótem: pndzmi`.

b Stowo zapisane skrótem: Sta'.

c-c Tekst wpisany w okrąg symbolizujący pieczęć, która znajdowata się w tym miejscu w oryginalnym dokumencie.

d Stowo zapisane skrótem: Rzpey'.

e-e Stowa zapisane skrótem: WKsL.

${ }^{29}$ Jansbork lub Jańsbork (niem. Johannisburg) - dzisiejsze miasto Pisz w województwie warmińsko-mazurskim w powiecie piskim. W XVII w. miasto to leżało $w$ granicach Prus Ksiażęcych.

30 Zob. przyp. 18.

31 Zob. przyp. 19.

32 Zob. przyp. 20.

33 Anna Maria Radziwitt (1640-1667) - córka i spadkobierczyni Janusza Radziwilta wojewody wileńskiego i hetmana wielkiego litewskiego, właściciela dóbr orlańskich i zabludowskich. Od 1665 r. żona Bogusława Radziwiłla. Testamenty ewangelików reformowanych $w$ Wielkim Księstwie Litewskim w XVI-XVIII w., wyd. U. Augustyniak, Warszawa 2014, s. 210-211.

${ }_{34}$ Aleksander Hilary Polubiński (1626-1679) - pisarz polny litewski w latach 1654-1669, nastęnie marszałek wielki litewski. M. Nagielski, Polubiński Aleksander Hilary [w:] PSB, t. XXVII, 1982-1983, s. 358-363.

35 Władysław Jerzy Chalecki (1606-1668) - straznik wielki litewski w latach 1656-1668. O. Halecki, Chalecki Władystaw Jerzy [w:] PSB, t. III, 1937, s. 252-253.

36 Samuel Kmicic (zm. 1692) - chorąży orszański w latach 1658-1676, następnie strażnik wielki litewski. T. Wasilewski, Kmicic Samuel [w:] PSB, t. XIII, 1967-1968, s. 81-83. 
P. Skowrodu ${ }^{37}$, P. Kieskiemu ${ }^{38}$ i jeśliby kto był z żołnierzów, pokazać tylko i dać przeczytać, ale samych nie oddawać, nawet ani kopii z nich nie dawać, tylko powiedzieć, gdyby się ich napierano, że Ks.J.M. odsyłać je do siebie kazał, aby miał dokument, że odebranie swego czyni z wolą J.K.M.

[I] ście $^{39}$ Ks.J.M. na Podlasie publikowaćc ${ }^{40}$ i preparacją na przyjęcie Ks.J.M. gotować, jakoż [k. 18v] prędzej by tam był szedł $\mathrm{z}$ wojskiem niż pod Kowno albo Wilno, gdzie ma iść propositum. Jeśliby PP. goście ${ }^{41}$ byli tak niedyskretni, żeby gospodarzowi dobrowolnie nie ustąpili, P. Skowrodkę upewnić afektem dobrym i respektem Ks.J.M., tylko niech życzliwość swoją pokaże w ustąpieniu Zabłudowa i w pomocy do tego, aby drudzy ustąpili. O toż amicabiliter P. Podolca ${ }^{42}$ rekwirować, powiedziawszy mu, że Ks.J.M. ma deklarację J.M.P. Pisarza [Wielkiego Księstwa Litewskiego], że restytucyjej nie będzie przeczny, ani miał za złe, gdy odbierze. Toż i J.M.P. Chorąży Orszański deklarował.

Tego postrzegać z P. Pisarzem Grodzkim Brańskim będą, aby nikomu gwałtu nie czyniono i surowie nie następowano, co też w osobliwym zleceniu i memoriale P. Kapitanowi Flokowi dano, ale modeste powiedzieć wszytkim, aby ustępowali, a poddanym wszytkim przykazać włości zabłudowskiej, orlańskiej, niewodnickiej, doylidzkiej, karakulskiej, białostockiej, żeby się im więcej nie wysługiwali, posłuszeństwa nie czynili; czynszów, żywności, podwód i nic zgoła nie dawali, a jeśliby nie ustępowali, a gwałty i bezprawia poddanym czynić chcieli, tedy przy dragonach bronić się niech będą gotowi.

$\mathrm{Na}$ to też mieć oko, żeby przy ustępowaniu poddanym bydeł, koni, zboża nie brali, a jeśli co podczas zajazdu wzięli albo immediate przed zajazdem i przechowali u PP. Sąsiad[ów], tedy u nich po przyjacielsku upomnieć się tego, a jeśliby wrócić nie chcieli, kazać odebrać, ale sąsiedzkiego nic nie brać i żadnego w ich domach gwałtu i bezprawia nie czynić.

Iż majętności niewodnickiej i doylidzkiej wieczność Ks.J.M. należy lubo są w zastawie, tedy do oswobodzenia ich z rąk żołnierskich, jako Ks.J.M. własnych dopomóc J.M.P. Marszałkowi Wiłkomirskiemu i inszym dzieci nieboszczyka ${ }^{a}$ P. Otten[h]auza opiekunom.

Rozkazać Ks.J.M. raczył, aby dragoni nie po gospodach, ale we dworach, w domu jednym [w] Zabłudowie i Orli stanęli i domy, w których stać będą, obwarować palisadą, do czego poddanych dla roboty dodać trzeba.

Ma i to w memoriale P. Kapitan, aby na wsi bez wiadomości PP. Urzędników nie posyłał i zabiegał temu, żeby poddani od żołnierzów żadnej ciężkości, krzywdy

a Stowo zapisane skrótem: Nieb.

37 Prokop Skworodka-urzędnik w dobrach zabludowskich z ramienia wojska litewskiego. Wcześniej stużyt w wojsku litewskim pod komenda Janusza Radziwitta.

38 Kieski - nieznany z imienia urzędnik $w$ dobrach zabludowskich z ramienia wojska litewskiego.

39 W znaczeniu: przyjście, nadejście.

40 W znaczeniu: rozglaszać, rozpowszechniać.

${ }^{41}$ W znaczeniu: żotnierze litewscy wraz z rodzinami i czeladzia.

42 Andrzej Kazimierz Podolec-sługa Aleksandra Hilarego Polubińskiego, petnit funkcję namiestnika orlańskiego z ramienia wojska litewskiego. 
i bezprawia nie ponosili, żeby ani gwałtem, ani potajemnie nic im nie brano i którzy by ważyli się dragoni takiej swej woli, aby jej bez folgi karał. I tego też przestrzegać powinien, aby sąsiedzkim wsiom królewskim i szlacheckim żadnej przykrości i szkody nie czynili.

A iż żołnierz bez sustentacyjej ${ }^{43}$ być nie może, tedy Ks.J.M. taką im naznacza jaką tu mieli, której rejestr daje się z pieczęcią Ks.J.M. Zarazem tedy P. Pisarz Grodzki Brański z PP. Urzędnikami wezwawszy do siebie magistratu z Zabłudowa i Orli, a wójtów ze wsiów ordynują, żeby taką sustentacyję co miesiąc na kapitana, oficerów i na dragony wydawano. Wszakże iż o pieniądze ${ }^{\mathrm{a}} \mathrm{w}$ tamtym kraju trudniej niż o żywność, tedy to skorygować, aby ad proportionem pieniędzy ${ }^{\mathrm{b}}$, żywność dawano, albo część pieniędzmic, część żywnością te ordynaryja [k. 19] raz w miesiąc oddawano. Przy której nie więcej P. Kapitan ma się, ani na dragony wyciągać nie ma, nawet żadnej posługi, ani podwody potrzebować i brać nie powinien. A jeśliby wsi które zwłaczały wydanie tej żywności, tedy dla wyciągania jej nie ma posyłać bez wiadomości starostów, ale im oznajmić, a oni kogo ze dworu dragonom zesłanym przydadzą dla prętszej tej żywności albo ordynaryjej żołnierskiej eksakcyjej.

Mieć i na to oku będą, jeśliż tak wiele będzie unter oficerów ${ }^{\mathrm{d} 44} \mathrm{i}$ dragonów, ile ich na regestrze położono i podług jego sustentacyję wydawać kazać.

Rozkazał Ks.J.M., aby P. Pisarz Grodzki Brański z P. Świniarskim ${ }^{45}$ dla pomocy wyprawienia tych gości z dóbr Ks.J.M. zjechał do Zabłudowa i Orli. Lecz jeśli i insi słudzy Ks.J.M. blisko mieszkający zasięgnieni do tego być mogą, tedy ich zażyć.

Ks.J.M. oznajmić jako na[j]prędzej de successu zajazdu tego i po tym często pisywać, dając znać o wszystkim, co się tam dziać będzie, a listy odsyłać tylko do Jansborka, skąd odsyłane będą. Mianowicie dać znać de statu włości i poddanym co grunty wzięli dworskie, wskazać, aby ich zasiewali jako na[j]lepiej, a nie tylko dworskie, ale i swoje własne. Czego z pilnością doglądać. Wywiedzieć się, wiele jest koni i wołów na włości i przysłać ich regestr Ks.J.M.

\section{Ordynaria miesięczna na kompanią kapitana Floka}

Kapitanowi tal. 30

Porucznikowi tal. 13 1/2

Chorążemu tal. 11 [gr] 22 1/2

Wachmistrzowi tal. 8

Podchorążemu tal. 2 [gr] 37 1/2
A servit $[i s]$ tal. 4

[A servitis] tal. 2

[A servitis] tal. $1 \frac{1 / 2}{2}$

\footnotetext{
Stowo zapisane skrótem: pndze`.

Stowo zapisane skrótem: pndzy'.

Stowo zapisane skrótem: pndzmi`.

W oryginale: oficierow.

W tym miejscu: ałe. Litera ,a” nadpisana nad skreśleniem.

W znaczeniu: wyżywienie, utrzymanie, zapłata.

${ }^{44}$ Wyraz pochodzacy od niemieckiego stowa: unteroffizier. Jeden ze stopni podoficerskich.

45 Stanisław Świniarski (zm. po 1668) - sługa Bogusława Radziwilta, urzędnik zabludowski od 1660 r. B. Radziwitt, op. cit., s. 350.
} 
Furierowi ${ }^{46}$ tal. 2 [gr] 37 1/2

Kapralowi ${ }^{a}$ Armensowi tal. 2 [gr] 37 1/2

Musterschreiberowi ${ }^{647}$ tal. 2 [gr] $371 / 2$

Kapralom 3 po tal. 2 gr $22 \frac{1}{2}-$ tal. 6 [gr] $671 \frac{1}{2}$

Doboszom 3 po tal. 2 - tal. 6

Cyrulikowi tal. $4 \frac{1}{2}$

Płacy czyni na miesiąc na oficery tal. 89 zł 2

Za servit [is] zaś tal. 7 zł 1 [gr] 15

Summa facit tal. 97 zł 0 gr 15

Przy tym ma być dragonów 50 komenderowanych ${ }^{\mathrm{c}}$, przy których będzie wachmistrz, podchorąży, kapral i dobosz.

[k. 19v] Wachmistrzowi tal. 8

Podchorążemu tal 2 [gr] 37 1/2

Kapralowi 1 tal. 2 [gr] 22 1/2

Doboszowi 1 tal. 2

Suma facit tal. 14 zł 2

Wyjdzie na miesiąc na oficerów tal. 111 zł 2 gr 15

A na dragonów ${ }^{\mathrm{d}} 150^{\mathrm{d}}$, kładąc na jednego ${ }^{\mathrm{e}}$ po tal. 2 , wyjdzie tal. 300

Wyjdzie tedy na miesiąc na oficery i dragony tal. 411 zł 2 gr 15

A złotych uczyni 1235 gr 15

\section{[Paszport dla kapitana Michata Floka i jego regimentu]}

Bogusław Radziwiłł Książę etc.

Wszem, wobec i każdemu z osobna, komu by o tym wiedzieć należało, oznajmuję, iż szlachetny Michał Flok, kapitan regimentu mego dragońskiego, idzie z rozkazania mego z dragonią moją na Podlasze i tam ma zostawać w majętnościach moich, aż do przyjazdu i dalszego ordynansu mego. Przez to, aby tam idąc, wolne miał prze[j]ście bez zatrudnienia i hamowania wszelkiego, i na miejscu zostawając, aby ${ }^{\mathrm{f}} \mathrm{za}^{\mathrm{f}}$ mego oficera ${ }^{\mathrm{g}}$ i ludzie przy nim będący za moich własnych poczytani byli, daję mu ten paszport $\mathrm{z}$ podpisem ręki i pod pieczęcią moją.

Data w Berlinie 20 augusti [20 VIII] 1660

a Slowo zapisane skrótem: cap.

b W oryginale: Monsterßrejberowi.

c W oryginale: commendyrowanych.

d-d Tekst podkreślony.

- Stowo zapisane skrótem: jedne ${ }^{\circ}$.

f-f Stowo „za” napisane nad tekstem pomiędzy „,aby” a „mego”.

g W oryginale: officiera.

${ }^{46}$ Furier-podoficer zajmujący się zakwaterowaniem i wyżywieniem jednostki wojskowej.

${ }^{47}$ Musterschreiber-pisarz w kompanii wojska. 


\section{BIBLIOGRAFIA}

\section{Źródła rękopiśmienne}

Archiwum Główne Akt Dawnych

Archiwum Warszawskie Radziwiłłów

dz. II, sygn. 1302, 1309, 1311, 1337

dz. IV, teka 4, koperta 51; teka 16, koperta 183

dz. IVa kopie, sygn. 745-746, 748

dz. V, sygn. 5226, 6865, 8916, 9646, 10816, 12196, 13276

Biblioteka Narodowa

Kopiariusz korespondencji Bogusława Radziwiłła oraz innych materiałów historycznych

i publicystyczno-literackich z lat 1657-1672, Rps III 3092

Narodowe Historyczne Archiwum Białorusi w Mińsku

f. 694: op. 1, sygn. 295

\section{Źródła drukowane}

Die Staatsverträge des Herzogtums Preussen, wyd. S.H. Dolezel, Köln 1971.

Metryka litewska. Księga wpisów nr 131, wyd. A. Rachuba, Warszawa 2001.

Poczobut Odlanicki J.W., Pamiętnik (1640-1684), wyd. I.J. Kraszewski, L. Potocki,

Warszawa 1877.

Poczobut Odlanicki J.W., Pamiętnik (1640-1684), wyd. A. Rachuba, Warszawa 1987.

Radziwiłł B., Autobiografia, wyd. T. Wasilewski, Warszawa 1979.

Testamenty ewangelików reformowanych $w$ Wielkim Księstwie Litewskim $w$ XVI-XVIII w., wyd. U. Augustyniak, Warszawa 2014.

Volumina Constitutionum, t. IV, vol. 1, oprac. K. Fokt, S. Grodziski, M. Kwiecień, Warszawa 2015.

Volumina Legum, t. V, oprac. J. Ohryzko, Petersburg 1860.

\section{Literatura przedmiotu i katalogi}

Augusiewicz S., Garnizon Birż w latach 1659-1687 i jego komendant Karol Karlick von Nezetitz [w:] Ustrój - polityka - kultura. Studia ofiarowane Profesor Stefanii Ochmann-Staniszewskiej, red. R. Kołodziej, J. Maroń, Wrocław 2011, s. 261-295.

Augusiewicz S., Przebudowa wojska pruskiego w latach 1655-1660. Uźródeł wczesnonowożytnej armii, Oświęcim 2014.

Boniecki A., Herbarz Polski, t. V, Warszawa 1902.

Halecki O., Chalecki Władystaw Jerzy [w:] Polski Słownik Biograficzny, t. III, red. W. Konopczyński, Kraków 1937, s. 252-253. 
Katalog rękopisów Biblioteki Narodowej, seria II, t. II: Rękopisy z Biblioteki Załuskich i innych zbiorów polskich zwrócone z Leningradu w latach 1923-1934: sygnatury 30063300, oprac. B.S. Kupść, K. Muszyńska, Warszawa 1980.

Konarski S., Platerowie [w:] Materiały do biografii, genealogii i heraldyki polskiej. Źródła i opracowania, t. IV, Buenos Aires-Paryż 1967.

Kossarzecki K., Kampania roku 1660 na Litwie, Zabrze 2005.

Lepszy K., Instrukcja wydawnicza dla źródet historycznych od XVI do połowy XIX w., Warszawa 1957.

Miłuński M., Zarząd dóbr Bogusława Radziwiłła w latach 1636-1669 [w:] Administracja $i \dot{z} y c i e$ codzienne $w$ dobrach Radziwittów XVI-XVIII w., red. U. Augustyniak, Fasciculi Historici. Seria Nowa, t. IX, Warszawa 2009, s. 195-284.

Nagielski M., Polubiński Aleksander Hilary [w:] Polski Słownik Biograficzny, t. XXVII, red. E. Rostworowski, Wrocław-Warszawa-Kraków-Gdańsk-Łódź 1982-1983, s. $358-363$.

Ostrowski J., Ksiega herbowa rodów polskich, Warszawa 1898.

Polska encyklopedia szlachecka, t. V, oprac. M. Dmowski, S.J. Strykoń-Kasprzycki, Warszawa 1936.

Rachuba A., Konfederacja Kmicicowska i Związek Braterski wojska litewskiego w latach 1660-1663, Warszawa 1989.

Rachuba A., Konfederacje wojska litewskiego w latach 1655-1663, Zabrze 2010.

Rachuba A., Oficerowie armii litewskiej z armii szwedzkiej $i$ oficerowie armii szwedzkiej $w$ armii litewskiej $w$ latach 1655-1660 [w:] Wojny pótnocne $w$ XVI-XVIII w. W czterechsetlecie bitwy pod Kircholmem, red. B. Dybaś, Toruń 2007, s. 151-163.

Rachuba A., Sprawa dóbr Radziwittów birżańskich w latach 1655-1662, „Miscellanea Historico-Archivistica" 1997, t. VII, s. 51-70.

Sierba M., Radziwiłtowskie dobra Orla (1585-1695), Białystok 2017.

Uruski S., Rodzina. Herbarz szlachty polskiej, t. IV, Warszawa 1907.

Wasilewski T., Kmicic Samuel [w:] Polski Stownik Biograficzny, t. XIII, red. E. Rostworowski, Wrocław-Warszawa-Kraków 1967-1968, s. 81-83.

Wasilewski T., Mierzeński Jan [w:] Polski Stownik Biograficzny, t. XXI, red. E. Rostworowski, Wrocław-Warszawa-Kraków-Gdańsk 1976, s. 18-20.

Wasilewski T., Walka o spadek po księżnej Marii Wołoszce, wdowie po Januszu Radziwille w latach 1660-1690, „Miscellanea Historico-Archivistica” 1989, t. III, s. 292-308.

Żojdź K., Jan Mierzeński. Klient i rezydent Bogusława Radziwiłta w latach 1656-1665, Oświęcim 2012. 